\section{Nutrient Concentrations, Growth, and Yield of Tomato and Squash in Municipal Solid-waste-amended Soil}

\author{
M. Ozores-Hampton ${ }^{1}$, B. Schaffer ${ }^{2}$, and H.H. Bryan ${ }^{3}$ \\ Tropical Research and Education Center, Institute of Food and Agricultural \\ Sciences, University of Florida, 18905 S. W. 280 Street, Homestead, FL 33031 \\ E.A. Hanlon ${ }^{3}$ \\ Soil and Water Science Department, Institute of Food and Agricultural \\ Sciences, University of Florida, Gainesville, FL 32611 \\ Additional index words. Lycopersicon esculentum, Cucurbita maxima, sewage sludge, trash \\ usage
}

\begin{abstract}
The effects of municipal solid waste (MSW) materials on growth, yield, and mineral element concentrations in tomato (Lycopersicon esculentum Mill.) (1991 and 1992) and squash (Cucurbita maxima Duch. Ex Lam.) (1992 and 1993) were evaluated. Agrisoil compost (composted trash), Eweson compost (co-composted trash and sewage sludge), or Daorganite sludge (chemically and heat-treated sewage sludge) were incorporated into calcareous limestone soil of southern Florida. The control had no MS W material added to the soil. The effect of MSW on crop growth, yield, and mineral element concentrations varied considerably between years for tomato and squash. In 1991, tomato plants grown in soil amended with Eweson or Daorganite had a greater canopy volume than plants in the control treatment. Tomato plants grown in Daorganite had greater total fruit weight (1991) than plants in Agrisoil and more marketable fruit (1992) than control plants. In both years, tomato plants in Agrisoil had higher root $\mathrm{Zn}$ concentrations than plants in the other treatments. In 1992, tomato plants in Eweson had lower root Mn concentrations than plants in the other treatments, whereas Mg concentrations in the roots were higher in the Daorganite treatment than in Eweson. Tomato plants in Agrisoil had higher Pb concentrations in the roots than plants in all other treatments. In 1991, leaves of tomato plants in Agrisoil had lower Ca concentrations than leaves of plants in the control treatment. In 1992, leaf $\mathrm{Zn}$ concentrations were greater for tomato and squash in Agrisoil than in the control or Daorganite. In 1992, canopy volume and yield of squash were greater for plants in Daorganite than for plants in the control and other MS W treatments. Although canopy volume and total squash fruit weight did not differ among treatments in 1993, plant height was greater for squash plants in the MSW treatments than for those in the control. In 1993, leaf $\mathrm{Mg}$ concentrations were greater for squash grown in Daorganite than for plants in the control or Agrisoil. In 1993, fruit Cd concentration was higher for plants with Eweson than for plants in the control or Agrisoil. However, the fruit Cd concentration in squash grown in Eweson compost $(1.0 \mathrm{mg} / \mathrm{kg}$ dry weight) was far below a hazardous level for human consumption. Our results indicate that amending calcareous soils with MSW materials can increase growth and yield of tomato and squash with negligible increases in heavy metal concentrations in fruit.
\end{abstract}

More than 180 million tons of municipal solid waste (MSW) materials are generated in the United States annually (Gillis, 1992). The greatest potential commercial use for this material is agricultural compost (Parr and Hot-nick, 1993).

Received for publication 7 Sept. 1993. Accepted for publication 26 Jan. 1994, Florida Agricultural Expt. Station Journal Series no. R-03393. This study was supported by grants from the Florida Center for Solid and Hazardous Waste Management and the Charles A. Lindbergh Fund. The cost of publishing this paper was defrayed in part by the payment of page charges. Under postal regulations, this paper therefore must be hereby marked advertisement solely to indicate this fact.

'Graduate Research Assistant.

${ }^{2}$ Professor, to whom reprint requests should be addressed.

${ }^{3}$ Professor. ity and organic matter (Bryan and Lance, 199 1). Adding MSW material may improve soil water- and nutrient-holding capacities. Also, the nutrient content of the soil may be increased due to the presence of low concentrations of essential elements in MSW materials (Chancy et al., 1980)

MSW materials often contain metals such as $\mathrm{Zn}, \mathrm{Al}, \mathrm{Cd}, \mathrm{Pb}, \mathrm{Fe}, \mathrm{Cu}, \mathrm{Mn}$, and Mo that may be phytotoxic or, if accumulated in the fruit, pose a health risk to humans (Chancy, 1980; Yuran and Harrison, 1986). In calcareous soils, such as those in southern Florida, heavy metals may not be available to the plant because they precipitate due to low volubility at the high $\mathrm{pH}$ of the soil (Street et al., 1978).

Our study was designed to determine the effects of MSW materials on nutrient concentration, growth, and yield of tomato and squash growing in calcareous soils of southern Florida

\section{Materials and Methods}

In 1991 and 1992, tomato ('Sunny') and squash ('Dixie') were planted in a single-year rotation at the Univ. of Florida, Tropical Research and Education Center, Homestead. The cultivars planted represent the major commercial cultivars in Dade County, Fla.

Tomato. In Feb. 1991 and in Jan. 1992,3week-old tomatoes grown from seed in flats were transplanted to polyethylene-covered beds, with $50 \mathrm{~cm}$ between plants and $1.8 \mathrm{~m}$ between rows. A different planting site was used each year. Insects and diseases were controlled following standard local practices.

In 1991, plants in all treatments were fertilized with $240 \mathrm{~kg} \mathrm{~N} / \mathrm{ha}$, of which $54 \%$ was applied in a granular form before planting and $46 \%$ was applied as a solution weekly during the growing period. Nitrogen was applied as $\mathrm{NH}_{4} \mathrm{NO}_{3}$ and $\mathrm{KNO}_{3}$. Before planting, a $6.0 \mathrm{~N}-$ $5.3 \mathrm{P}-10.0 \mathrm{~K}$ granular fertilizer was applied at $1800 \mathrm{~kg} \cdot \mathrm{ha}^{-1}$ in two bands $50 \mathrm{~cm}$ apart. The fertilizer was rototilled $10 \mathrm{~cm}$ into the bed, and two bands $(12.5 \mathrm{~cm}$ apart) of $2.0 \mathrm{~N}-13.2 \mathrm{P}$ $3.3 \mathrm{~K}-2.4 \mathrm{Mg}$ at $900 \mathrm{~kg} \cdot \mathrm{ha}^{-1}$ were placed in the center of the bed. Beginning at flowering, liquid fertilizer was injected though a dripirrigation system twice each week for 7 weeks at an average rate of $2.25 \mathrm{~kg} \mathrm{~N} / \mathrm{ha}$ per day.

In 1992, cultural practices for tomato followed those of the 1991 tomato experiment with the following exceptions: all plants were fertilized with $225 \mathrm{~kg} \mathrm{~N} / \mathrm{ha}$, of which $68 \%$ was applied in a granular form before planting and $32 \%$ was applied as a solution weekly during the growing period. Before planting, an $8.0 \mathrm{~N}-$ 7.0P-13.3K granular fertilizer was applied at $1686 \mathrm{~kg} \cdot \mathrm{ha}^{-1}$ in two bands $50 \mathrm{~cm}$ apart, and after rototilling, a $2.0 \mathrm{~N}-11.0 \mathrm{P}-3.3 \mathrm{~K}-1.2 \mathrm{Mg}$ granular fertilizer was applied at $900 \mathrm{~kg} \cdot \mathrm{ha}^{-1}$ in two bands at the center of the bed. Liquid fertilizer was injected once each week for 5 weeks at an average rate of $2.05 \mathrm{~kg} \mathrm{~N} / \mathrm{ha}$ per day, beginning at flowering.

Squash. To test residual effects of MSW in the soil on growth and yield of a second crop, squash was planted in Oct. 1992 and Nov. 1993 on the same beds used previously for the tomato crops. Squash plants were direct-seeded 
Table 1. Concentration of mineral elements in three municipal solid waste (MSW) materials.

\begin{tabular}{lccc}
\hline & \multicolumn{3}{c}{ MSW material } \\
\cline { 2 - 4 } Element & Agrisoil & Eweson & Daorganite \\
\hline \multicolumn{4}{c}{ Concentration $(\%$ dry wt) } \\
$\mathrm{N}$ & 0.48 & 1.18 & 3.19 \\
$\mathrm{P}$ & 0.14 & 0.98 & 1.72 \\
$\mathrm{~K}$ & 0.28 & 0.64 & 0.11 \\
$\mathrm{Ca}$ & 0.12 & 1.55 & 14.95 \\
$\mathrm{Mg}$ & 0.003 & 0.009 & 0.006 \\
$\mathrm{Fe}$ & 0.002 & 2.71 & 0.95 \\
$\mathrm{~S}$ & 0.022 & 0.11 & 1.37 \\
& Concentration & $($ mg $/ \mathrm{kg}$ dry wt) \\
$\mathrm{Cd}$ & 4.1 & 3.7 & 18.0 \\
$\mathrm{Cu}$ & 246.0 & 350.0 & 537.0 \\
$\mathrm{Ni}$ & 34.0 & 12.0 & 67.0 \\
$\mathrm{~Pb}$ & 124.0 & 21,7 & 212.0 \\
$\mathrm{Zn}$ & 607.0 & 510.0 & 1180.0 \\
\hline
\end{tabular}

in two rows on each bed. Plant spacing was $37.5 \mathrm{~cm}$ between rows and $37.5 \mathrm{~cm}$ between planting holes within rows. Each planting hole contained two plants. Between-bed spacing was $1.8 \mathrm{~m}$. Insects and diseases were controlled following local standard agricultural practices.

All plants received $120 \mathrm{~kg} \mathrm{~N} / \mathrm{ha} ; 50 \%$ was applied in a granular form at planting, and $50 \%$ was applied as a solution during the growing period. Nitrogen was applied as $\mathrm{NH}_{4} \mathrm{NO}_{3}$ and $\mathrm{KNO}_{3}$. At planting, a granular 8.0N-7.0P-13.3K fertilizer was applied at 750 $\mathrm{kg} \cdot \mathrm{ha}^{-1}$ in two bands $50 \mathrm{~cm}$ apart and rototilled $10 \mathrm{~cm}$ into the bed. Liquid fertilizer was injected though a drip-irrigation system once each week for 3 weeks at an average rate of 2.9 $\mathrm{kg} \mathrm{N} / \mathrm{ha}$ per day beginning at flowering.

MSW treatments. Treatments consisted of the following sources of MSW materials incorporated into the soil: 1 ) a control, with no MSW incorporated into the soil, 2) Agnsoil compost, composed of composted household and yard trash (Agripost, Miami) applied at 48 $\mathrm{Mg} \cdot \mathrm{ha}^{-1}$; 3) Eweson compost, composed of composted household trash and sewage sludge (Bedminster Bioconversions, Big Sandy, Texas) applied at $24 \mathrm{Mg} \cdot \mathrm{hah}^{-1}$; and 4) Daorganite sludge, composed of chemically and heattreated sewage (produced by Metro-Dade County, Fla. and distributed by the South Dade Soil and Water Conservation District, Homestead, Fla.) applied at $16 \mathrm{Mg} \cdot \mathrm{ha}^{-1}$. Application rates for Daorganite were based on results from previous research (Bryan and Lance, 1991 ). Application rates of Eweson and Agrisoil composts were recommended by the producers, based on tests in growers' fields in southern Florida. Each MSW material was applied one time before planting in a 45$\mathrm{cm}$-wide strip with a steel belt distributor (Kennco Manufacturing, Ruskin, Fla.) and rototilled $10 \mathrm{~cm}$ into the bed. Producers provided mineral element concentrations in each of the MSW materials (Table 1).

The design was a randomized complete block. Plots were $18 \mathrm{~m}$ long and $60 \mathrm{~cm}$ wide, with 30 plants per plot for tomato and 60 plants per plot for squash. There were four singleplot replications for each treatment.

Data collection and analysis. The effects of MSW on crop growth, yield, and mineral element concentrations in plant organs were determined for each crop in each year. Plant height (from soil surface to the top of the canopy) and canopy width (at the widest point) were measured immediately before the first harvest. Canopy volume was determined by multiplying the plant height by the canopy width (within row) by canopy width (across row). Yield was recorded for all crops as total fruit weight and number per plant and per plot. Tomato fruit sizes (diameters) were large $(>6.5$ $\mathrm{cm})$, medium $(6.5-5.5 \mathrm{~cm})$, and small $(<5.5$ $\mathrm{cm})$. Large and medium tomato fruit were considered marketable. Plant height and canopy volume were recorded as means for $\geq 36$ plants per treatment (nine plants per plot) and yields were recorded from all plants in each treatment.

For mineral analysis of plant tissues, 60 leaflets (from the three most recently fully expanded leaves on each plant) and 15 fruit were randomly collected from plants in each plot immediately before the first harvest; 30 root samples were collected from plants in each plot after the last harvest. Leaf, root, and fruit samples were washed in tap and then distilled water, dried at $60 \mathrm{C}$, and ground to a powder with a cyclone grinder (UDY Corp., Fort Collins, Colo.). Nitrogen concentration was determined calorimetrically with a rapid flow analyzer (ALPKEM, Clackamas, Ore.) as described by Hanlon and DeVore (1989). Concentrations of $\mathrm{P}, \mathrm{K}, \mathrm{Ca}, \mathrm{Na}, \mathrm{Mg}, \mathrm{Al}, \mathrm{Cu}$, $\mathrm{Fe}, \mathrm{Mn}, \mathrm{Pb}, \mathrm{Ni}, \mathrm{Cd}$, and $\mathrm{Zn}$ were determined with an inductively coupled, argon plasma spectroscope (Model 9000; Jarrel-Ash, Waltham, Mass.).

Data were analyzed by analysis of variance and Duncan's multiple range tests.

\section{Results and Discussion}

There were significant interactions $(P \leq$ 0.05 ) between year and MSW for many of the variables tested for each crop. Therefore, data for each crop were analyzed separately by year to determine the effects of MSW on plant growth, yield, and mineral element concentrations. Data are reported in tables only when there were significant $(P \leq 0.05)$ MSW effects. For all other variables, there were no significant MSW effects.

In 1991, damage to some tomato plants, possibly due to contaminated fungicide, resulted in an uneven number of healthy plants per treatment. Therefore, yield was expressed as fruit fresh weight per plant. In 1992, tomato fruit yields were in the range of those obtained by growers for plants on the same soil.

Amending soil with Daorganite inconsistently increased growth and yield of tomato and squash, whereas Eweson and Agrisoil composts inconsistently increased growth but not yield (Table 2). In previous studies, amending southern Florida soil with Daorganite at a rate as low as $6.8 \mathrm{Mg} \cdot \mathrm{ha}^{-1}$ resulted in increased yields of several vegetable crops (Bryan and Lance, 1991). In those studies, increased growth and yield for plants grown in Daorganite were attributed to the addition of $\mathrm{N}$ to the soil. Sewage sludge contains $\mathrm{N}$ in slowly available forms, which can enhance plant growth due to improved nutrition (Chancy et al., 1980). In our study, the MSW application rates were adjusted to add about the same amount of $\mathrm{N}$ in each MSW treatment. However, the mineralization rate of $\mathrm{N}$ from Daorganite may have been greater than that of Eweson and Agrisoil composts. Thus, the higher fruit yields in the Daorganite treatment may have been due to an effect of increased $\mathrm{N}$ availability. Although there were no significant differences in plant $\mathrm{N}$ concentrations among MSW treatments, the increased growth of plants in Daorganite may have resulted in a dilution of $\mathrm{N}$ (i.e., higher total $\mathrm{N}$ accumulation per plant in Daorganite), thus masking differences in $\mathrm{N}$ on a tissue dry weight basis among treatments.

Our fertilizer rates were similar to those used in standard commercial practice in southern Florida. In concurrent studies on Krome very gravelly loam soil, similar growth and yield responses were observed for tomato and squash on nonamended soil using one-third of the amount of inorganic fertilizer applied in this study (Ozores-Hampton et al., unpublished data). However, Krome very gravely loam soil is porous and has a poor nutrient-and water-holding capacity. Therefore, growers often apply large amounts of inorganic fertilizer to offset nutrient losses due to leaching during rainy periods. The lack of yield responses with Eweson and Agrisoil composts may have been due to suboptimal application rates of these composts or to optimum rates of inorganic fertilizer for all treatments, masking the effects of $\mathrm{N}$ from the compost. Although these composts have a lower $\mathrm{N}$ concentration than Daorganite, they have a higher organic matter content. Most benefits of composted household and yard trash applications to soil have been attributed to improved physical properties of the soil due to increased organic matter content (Gallardo-Lora and Nogales,

Table 2. Growth and yield of tomato (1991 and 1992) and squash (1992 and 1993) plants in soil amended with municipal solid waste (MSW) materials or a nonamended control.

\begin{tabular}{|c|c|c|c|c|c|c|}
\hline \multirow[b]{3}{*}{ MSW } & \multicolumn{3}{|c|}{ Tomato } & \multicolumn{3}{|c|}{ Squash } \\
\hline & \multicolumn{2}{|c|}{1991} & \multirow{2}{*}{$\begin{array}{c}1992 \\
\text { No, fruit/ha }\end{array}$} & \multicolumn{2}{|c|}{1992} & \multirow{2}{*}{$\begin{array}{c}1993 \\
\text { Plant ht } \\
(\mathrm{cm})\end{array}$} \\
\hline & $\begin{array}{l}\text { Canopy vol } \\
\left(1000 \mathrm{~cm}^{3}\right)\end{array}$ & $\begin{array}{c}\text { Total fruit wt } \\
\text { (g/plant) }\end{array}$ & & $\begin{array}{l}\text { Canopy vol } \\
\left(1000 \mathrm{~cm}^{3}\right)\end{array}$ & $\begin{array}{l}\text { Total fruit wt } \\
\left(\mathrm{Mg} \cdot \mathrm{ha}^{-1}\right)\end{array}$ & \\
\hline None (control) & $54.6 \mathrm{~b}^{\mathrm{y}}$ & $110 \mathrm{ab}$ & $393 \mathrm{~b}$ & $3.19 \mathrm{~b}$ & $5.3 \mathrm{~b}$ & $26.2 \mathrm{~b}$ \\
\hline Agrisoil & $73.1 \mathrm{ab}$ & $89 \mathrm{~b}$ & $400 \mathrm{ab}$ & $3.38 \mathrm{ab}$ & $5.5 \mathrm{~b}$ & $29.8 \mathrm{a}$ \\
\hline Eweson & $93.2 \mathrm{a}$ & $121 \mathrm{ab}$ & $419 \mathrm{ab}$ & $3.42 \mathrm{~b}$ & $6.0 \mathrm{ab}$ & $29.7 \mathrm{a}$ \\
\hline Daorganite & $82.2 \mathrm{a}$ & $182 \mathrm{a}$ & $459 \mathrm{a}$ & 3,65 a & $6.9 \mathrm{a}$ & $30.2 \mathrm{a}$ \\
\hline
\end{tabular}

${ }^{2}$ Number of fruit per hectare $\times 1000$.

'Mean separation among treatments by Duncan's multiple range test $(P \leq 0.05)$. 
1987) rather than to their value as fertilizers. Therefore, adding these materials to soils low in organic matter may increase water- and nutrient-holding capacity of the soil, thereby increasing crop productivity. However, the application rates possibly were too low to significantly increase soil water- and nutrientholding capacity sufficiently to increase yield. This assumption is supported by the fact that adding these MSW materials to the soils did not increase concentrations of any macronutrient in the plants.

Although household trash and sewage sludge may contain substantial quantities of heavy metals (Chancy, 1980), adding some MSW materials to the soil only increased root $\mathrm{Zn}$ and $\mathrm{Pb}$ concentrations (Table 3), leaf $\mathrm{Zn}$ concentrations (Table 4), and fruit Cd concentrations (Fig. 1) compared to the control. In 1992, tomato plants grown in Eweson had lower Mn concentrations in roots than plants in the other treatments, and plants in Daorganite had higher $\mathrm{Mg}$ concentrations in roots than plants grown in Eweson (Table 3). In 1993, $\mathrm{Mg}$ concentrations in squash leaves were higher for plants in Daorganite than for plants in Agrisoil or the control (Table 4). Although there were significant differences in concentrations of some nutrients among MSW treatments, no symptoms of nutrient toxicity or deficiency were observed for either crop during either year. Also, the concentration of all mineral elements in the leaves were in the sufficiency ranges for tomato (Jones et al., 1991 ) in 1991 and squash (Hochmuth et al., 1991) in 1992 and 1993. In 1992, concentrations of all elements in tomato leaves were in the sufficiency range except for $\mathrm{Zn}$ and $\mathrm{Mn}$ concentrations, which were slightly lower than the sufficiency range for plants in all treatments except Agrisoil (Jones et al., 1991). Similarly, in a study with corn (Zea mays L.), amending soil with sewage sludge resulted in heavy metal concentrations in the grain and ear leaf within ranges considered normal for healthy plants (Reed et al., 1991).

Of the heavy metals likely to accumulate in fruit, $\mathrm{Cd}$ traditionally has been considered the most serious risk to human health (Chancy, 1990). Chronic exposure to $\mathrm{Cd}$ has been linked to nervous disorders and hypertension (Schroeder, 1967), and the intake of high levels of Cd can lead to kidney damage (Ryan et al., 1982). In a recent review of public health issues related to MSW composts, Chancy (1991 ) asserted that increased Cd uptake due to MSW is too low to pose a serious health threat. We observed variability between crops and years for the effect of MSW on Cd concentration in the fruit; the MSW application increased fruit $\mathrm{Cd}$ concentration only for squash grown in 1993 (Fig. 1). This variability was not surprising because Yuran and Harrison (1986) found a great deal of genotypic variation in plant Cd uptake when 60 cultivars of noncrisphead lettuce were grown in sewage sludge. The 10-fold increase in Cd concentration in squash fruit in the Eweson treatment compared with the control was not high enough to pose a threat to human health if ingested (Chancy, 1980). The recommended, safe maxi- mum, average daily dietary intake of $\mathrm{Cd}$ is 70 $\mu \mathrm{g} \cdot \mathrm{day}^{-1}$ (Chancy, 1990). Squash fruit is composed of $\approx 94 \%$ water (Lorenz and Maynard 1980); therefore, the $1 \mathrm{mg} \mathrm{Cd} / \mathrm{kg}$ fruit dry weight for squash grown in Eweson compost (Fig. 1) is equivalent to $\approx 10.6 \mu \mathrm{g} \mathrm{Cd} / \mathrm{kg}$ fruit fresh weight. Thus, it would be necessary to consume an unrealistic quantity ( $\approx 6.6 \mathrm{~kg}$ ) of fresh fruit per day to pose a threat to human health. Similar to our observations, when other vegetable crops and tomato were grown in sewage sludge, $\mathrm{Zn}$ and $\mathrm{Cd}$ did not accumulate to levels high enough to be toxic to plants or hazardous for humans (Falahi-Ardakani et al., 1987a, 1987b). In a study using sewage sludge with a high metal content, the Cd concentrations in the edible portions of corn were low regardless of the source of compost in the transplant media (Street et al., 1978). In that study, volubility of $\mathrm{Cd}$ in the soil was dramatically reduced at $\mathrm{pHs}>7.25$. The $\mathrm{pH}$ of southern Florida soil is 7.2 to 7.6 (Larson et al., 1991 ), and Cd is most likely precipitated due to low volubility at the high $\mathrm{pH}$. In a glasshouse study with cucumber (Cucumis sativus L.) grown in sewage sludge in containers, $\mathrm{Cd}$ concentrations in fruit did not accumulate to levels hazardous to human health over a range

Table 3. Concentrations of $\mathrm{Zn}, \mathrm{Mn}, \mathrm{Mg}$, and $\mathrm{Pb}$ in roots of tomato ( 1991 and 1992) grown in soil amended with municipal solid waste (MSW) materials or a nonamended control treatment.

\begin{tabular}{lccccc}
\hline \hline & \multicolumn{5}{c}{ Tomato } \\
\cline { 2 - 6 } & 1991 & \multicolumn{5}{c}{1992} \\
\cline { 2 - 6 } MSW & $\begin{array}{c}\mathrm{Zn} \\
(\mathrm{mg} / \mathrm{kg} \mathrm{dry} \mathrm{wt})\end{array}$ & $\begin{array}{c}\mathrm{Zn} \\
(\mathrm{mg} / \mathrm{kg} \text { dry wt })\end{array}$ & $\begin{array}{c}\mathrm{Mg} \\
(\mathrm{mg} / \mathrm{kg} \text { dry wt })\end{array}$ & $\begin{array}{c}\mathrm{Pb} \\
(\mathrm{mg} / \mathrm{kg} \text { dry wt })\end{array}$ \\
\hline None (control) & $31.8 \mathrm{c}^{\mathrm{z}}$ & $43.0 \mathrm{c}$ & $58.3 \mathrm{a}$ & $0.200 \mathrm{ab}$ & $11.1 \mathrm{~b}$ \\
Agrisoil & $59.7 \mathrm{a}$ & $69.7 \mathrm{a}$ & $57.4 \mathrm{a}$ & $0.200 \mathrm{ab}$ & $13.5 \mathrm{a}$ \\
Eweson & $40.2 \mathrm{~b}$ & $55.4 \mathrm{~b}$ & $45.7 \mathrm{~b}$ & $0.218 \mathrm{~b}$ & $10.0 \mathrm{~b}$ \\
Daorganite & $44.2 \mathrm{~b}$ & $55.6 \mathrm{~b}$ & $55.8 \mathrm{a}$ & $0.220 \mathrm{a}$ & $11.1 \mathrm{~b}$ \\
\hline
\end{tabular}

${ }^{2}$ Mean separation among treatments by Duncan's multiple range test $(P \leq 0.05)$.

Table 4. Leaf Ca, Zn, and Mg concentrations in tomato ( 1991 and 1992) and squash ( 1992 and 1993) plants grown in soil amended with municipal solid waste (MSW) materials or a nonamended control treatment.

\begin{tabular}{|c|c|c|c|c|}
\hline & \multicolumn{2}{|c|}{ Tomato } & \multicolumn{2}{|c|}{ Squash } \\
\hline & 1991 & 1992 & 1992 & 1993 \\
\hline MSW & $\begin{array}{c}\mathrm{Ca} \\
(\% \text { dry wt) }\end{array}$ & $\begin{array}{c}\text { Zn } \\
\text { (mg/kg dry wt) }\end{array}$ & $\begin{array}{c}\mathrm{Zn} \\
\text { (mg/kg dry wt) }\end{array}$ & $\begin{array}{c}\mathrm{Mg} \\
(\% \text { dry wt) }\end{array}$ \\
\hline None (control) & $4.0 \mathrm{a}^{2}$ & $16.4 \mathrm{~b}$ & $49,1 \mathrm{~b}$ & $0.46 \mathrm{~b}$ \\
\hline Agrisoil & $3.5 \mathrm{~b}$ & $25.7 \mathrm{a}$ & $56.7 \mathrm{a}$ & $0.46 \mathrm{~b}$ \\
\hline Eweson & $3.8 \mathrm{ab}$ & $19.3 \mathrm{ab}$ & $52.9 \mathrm{ab}$ & $0.50 \mathrm{ab}$ \\
\hline Daorganite & $3.8 \mathrm{ab}$ & $16.6 \mathrm{~b}$ & $50.9 \mathrm{~b}$ & $0.51 \mathrm{a}$ \\
\hline
\end{tabular}

Mean separation among treatments by Duncan's multiple range test $(P \leq 0.05)$.

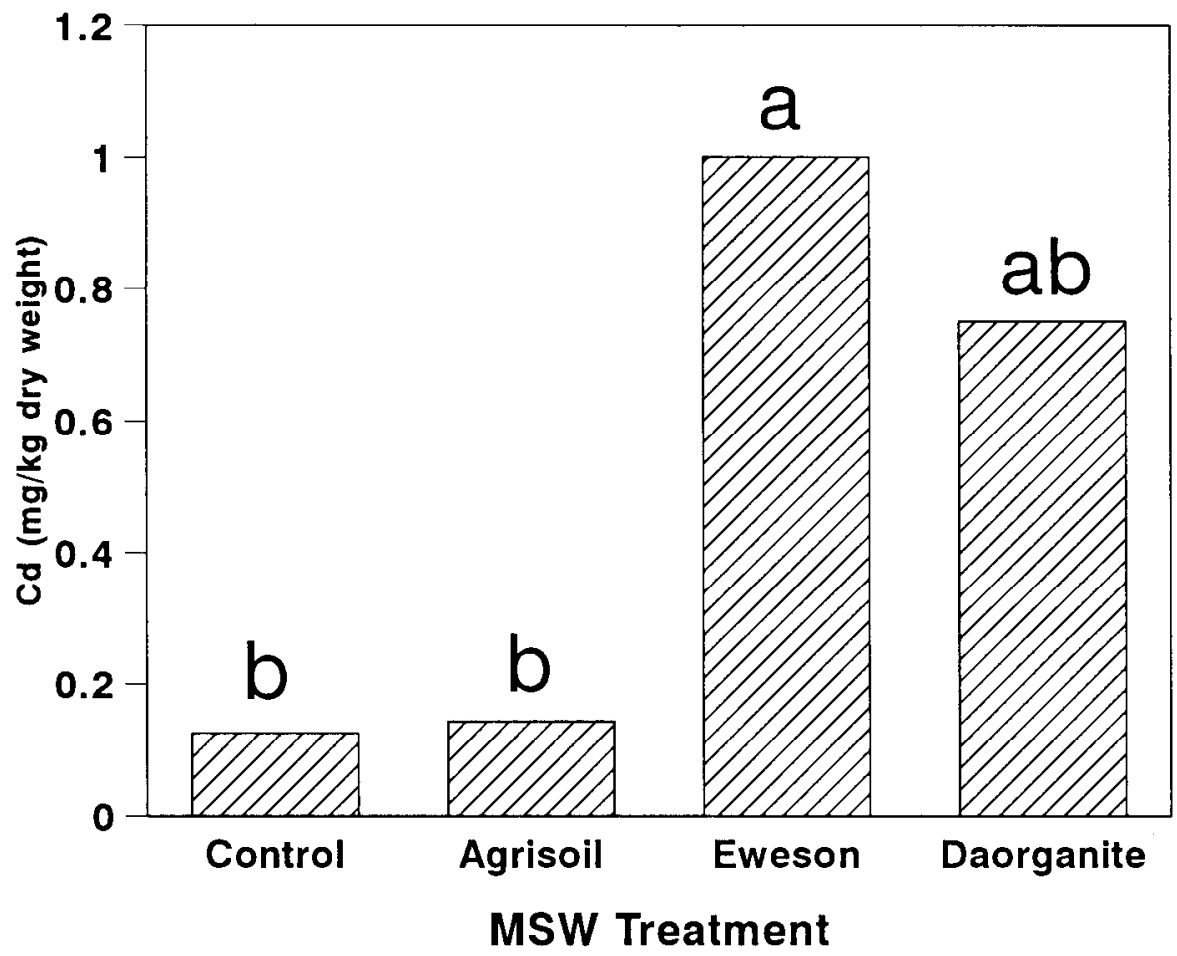

Fig. 1. Fruit Cd concentrations in squash plants grown in soil amended with municipal solid waste (MSW) materials or a nonamended control treatment (1993). Mean separation among treatments by Duncan's multiple range test $(P \leq 0.05)$. 
of soil $\mathrm{pH}$ values (Falahi-Ardakani et al., 1988).

In 1991, tomato leaf $\mathrm{Ca}$ concentrations were higher in control plants than in plants grown in Agrisoil treatments (Table 4). Krome very gravelly loam soil is derived from limestone, and therefore, the $\mathrm{Ca}$ concentration is high (4-8 $\mathrm{mg} \mathrm{Ca} / \mathrm{g}$ dry weight soil) (Larson et al., 199 1). The addition of MS W may have diluted the $\mathrm{Ca}$ in the immediate vacinity of the roots.

Amending calcareous soils with MSW material can increase growth and yield of tomato and squash. In agreement with previous studies (Sterrett et al., 1982, 1983), amending soil with sewage sludge did not result in tissue heavy metal concentrations considerably higher than in plants in nonamended soil. Likewise, adding of composts produced from household and yard trash to Krome very gravelly loam soil did not result in plant heavy metal concentrations that were significantly higher than those of plants grown in nonamended soil. Therefore, in addition to sewage sludge, using MSW composts derived from household and yard trash for vegetable production appears to be a practical alternative to other disposal methods, such as incineration or burial in land fills. Fertilizer and water are not limited in the agricultural area of southern Florida and were not limited in this study. However, due to increasing urbanization and concerns about water quality and quantity, fertilization and irrigation are likely to be carefully regulated in the future. Therefore, the addition of MSW materials to southem Florida soil maybe beneficial for increasing water and nutrient holding capacity of the soil. Preliminary data with higher rates of Eweson (30 Mg dry weight/ha) indicate significant yield increases for tomato and squash compared to plants in nonamended soil (Schaffer and Bryan, unpublished data). Further studies using higher MSW application rates for several years on the same sites with different irrigation rates need to be conducted to test residual compost effects on growth, yield, and mineral element concentration of crops grown in calcareous soils as well as the persistence of these materials in the soil.

The limited crop growth and yield increases resulting from the MSW rates used under the conditions described in this study would not justify the additional expense to tomato and squash growers of purchasing and applying
MSW materials. One solution to the potentially low cost : benefit ratio of MSW for growers may be for MSW manufacturers to obtain operating costs from disposal fees (commonly done at land fills) and to provide MSW to growers free of charge. Thus, if increases in crop production are not substantial enough to justify purchasing MSW, the use of these materials may still provide a viable waste disposal alternative.

\section{Literature Cited}

Bryan, H.H and C.J. Lance. 1991. Compost trials on vegetables and tropical crops. Biocycle 27:3637.

Chancy, R.L. 1980, Health risks associated with toxic metals in municipal sludge, p. 59-83. In: G. Bitton, B. Damron, G. Edds, and J. Davidson (eds.), Sludge-Health risks of land application. Ann Arbor Sci. Publ. Ann Arbor, Mich.

Chancy, R.L. 1990. Food chain impact, public health and sludge utilization. Part II. Biocycle 31:6873 .

Chancy, R.L. 1991. Land application of composted municipal solid waste: Public health, safety, and environmental issues. Proc. Natl. Conf. Solid Waste Comporting Council, Falls Church, Vs., 13-15 Nov. 1991

Chancy, R. L., J.B. Munns, and H.M. Cathey. 1980 Effectiveness of digested sewage sludge compost in supplying nutrients for soilless potting media. J. Amer. Soc. Hort. Sci. 105:485492.

Falahi-Ardakani, A, J.C. Bouwkamp, F.R. Gouin, and R.L. Chancy, 1987a, Growth response and mineral uptake of vegetable transplants grown in a, composted sewage sludge amended medium. I. Nutrient supplying power of the medium. J. Environ. Hort. 5: 107-111.

Falabi-Ardakani, A., K.A. Corey, and F.R. Gouin, 1988. Influence of $\mathrm{pH}$ on cadmium and zinc concentrations of cucumber grown in sewage sludge. HortScience 23:1015-1017.

Falahi-Ardakani, A., F.R. Gouin, J.C. Bouwkamp, and R.L. Chancy. 1987b. Growth response and mineral uptake of vegetable transplants grown in composted sewage-amended sludge medium. IL Influenced by time of application of $\mathrm{N}$ and $\mathrm{K}$. J. Environ. Hort. 5:112-115.

Fitzpatrick, G. and N.S. Carter. 1983. Assessment of sewage sludge compost mixtures as container growing media. Proc. Fla. State Hort. Soc. 96:257-259.

Fitzpatrick, G. and W.R. Farrel. 1984. Florida county puts end use first. Biocycle 24:42-44.

Gallardo-Lora, F. and R. Nogales. 1987. Effect of the application of town refuse compost on the soil-plant system A review. Biol. Wastes 103562.
Gillis, A.M. 1992. Shrinking the trash heap. Bioscience 42:90-93.

Hanlon, E.A. and J.M. DeVore. 1989. IFAS extension soil testing laboratory chemical procedures and training manual. Univ. of Florida, Inst. of Food and Agr. Sci., Coop. Ext. Serv. Circ. 812, Gainesville.

Harrison, H. C.” and J.E. Staub. 1986. Effects of sludge, bed and genotype on cucumber growth and elemental concentrations in fruit and peel. J. Amer. Soc. Hort. Sci. 11 1:209-211.

Hochmuth, G., D. Maynard, C. Vavarina, and E.A. Hanlon. 1991. Plant tissue analysis and interpretation for vegetable crops in Florida. Univ. of Florida Coop. Ext. Serv. Publ. SS-VEC-42, Gainesville.

Jones, J.B., Jr., B. Wolf, and H.A. Mills. 1991. Plant analysis handbook A practical sampling, preparation, analysis, and interpretation guide. Micro-Macro Publishing, Athens, Ga.

Larson, K. D., D.A. Graetz, and B. Schaffer. 1991. Flood-induced chemical transformations in calcareous agricultural soils of south Florida. Soil Sci. 152:33-40.

Lorenz, O.A, and D.N. Maynard. 1980. Knott's handbook for vegetable mowers. Wiley and Sons, New York,

Parr, J.F. and S.B. Homick, 1993. Utilization of municipal wastes. In: F.B. Metting (cd.). Soil microbial ecology: Application in agriculture, forestry, and environmental management. Marcel Dekker, New York.

Reed, B.E., P.E. Carriere, and M.R. Matsumoto. 1991. Applying sludge on agricultural land. Biocycle 32:58-60.

Ryan, J.A., H.R. Pahren, and J.B. Lucas. 1982. Controlling cadmium in the human food chain: A review and rationale based on health effects. Environ. Res. 28:251-302.

Schroeder, H.A. 1967. Cadmium as a factor in hypertension. J. Chronic Dis. 18:647-656.

Sterrett, S.B., R.L. Chancy, C.W. Reynolds, F.D. Schales, and L.W. Douglas. 1982. Transplant quality and metal concentration in vegetable transplants grown in media containing sewage sludge compost. HortScience 17:920-922.

Sterrett, S.B., R.L. Chancy, C.W. Reynolds, F.D. Schales, and L.W. Douglas. 1983. Transplant quality, yield and heavy metal accumulation of tomato, muskmelon and cabbage grown in media containing sewage sludge compost. J. Amer. Soc. Hort. Sci. 108:36-41.

Street, J. B., R. Sabely, and W.L. Lindsay. 1978. Influence of $\mathrm{pH}$, phosphorus, cadmium, sewage sludge, and incubation time on the volubility and plant uptake of cadmium. J. Environ. Qual. 7:286-290.

Yuran, G.T. and H.C. Harrison. 1986. Effects of genotype and sludge on cadmium concentration in lettuce leaf tissue. J. Amer. Soc. Hort. Sci. 111:491494. 